\title{
Partisipasi Masyarakat Pada Pengelolaan Banjir Kota Gorontalo
}

\author{
Mohammad Sofyan ${ }^{\mathrm{a}, 1, *}$, Soleh ${ }^{\mathrm{b}, 2}$ \\ ${ }^{a}$ Institut Ilmu Sosial dan Manajemen STIAMI, Jakarta, Indonesia \\ ${ }^{\mathrm{b}}$ Fakultas Ilmu Sosial dan Ilmu Politik Universitas Wiralodra, Indramayu, Indonesia \\ 1 sofyan@stiami.ac.id* \\ * corresponding author
}

\section{ARTICLE INFO}

\section{Article history}

Received

Revised

Accepted

Keywords

Society participation

Flood control

Stakeholder Analysis

\begin{abstract}
The community and several agencies the city of Gorontalo especially those directly related to the presence of the Bolango river show that their not to their satisfaction of the work because the community considers the work performed by the subproject has not been completed. The benefits in terms of flood control projects that were considered less been of more benefit value. Indeed, if the making embankments can be solved, then the value of benefits from the existence of the project will be very high because the area is secured a growing urban region that is generally a business district/trading area.
\end{abstract}

\section{A. PENDAHULUAN}

Salah satu Intruksi Presiden No 4 tahun 2012 tentang Penanggulangan Banjir dan Longsor adalah mendorong tingkat partisipasi masyarakat. Partisipasi masyarakat merupakan suatu proses teknis untuk memberikan kesempatan dan wewenang yang lebih luas kepada masyarakat untuk secara bersama-sama memecahkan berbagai persoalan pada umumnya, khususnya dalam konteks pengendalian banjir baik dalam pembangunan fisik maupun non fisik pengendali banjir. Pembagian kewenangan ini dilakukan berdasarkan tingkat keikutsertaan (level of involvement) masyarakat dalam kegiatan tersebut. Partisipasi masyarakat bertujuan untuk mencari solusi permasalahan yang lebih baik dalam suatu komunitas dengan membuka lebih banyak kesempatan bagi masyarakat untuk ikut memberikan kontribusi baik pada fase pra konstruksi, tahap kontruksi, maupun paska konstruksi pembangunan disik pengendali banjir. Dengan hal tersebut diharapkan implementasi kegiatan berjalan aman lebih efektif, efesien, dan berkelanjutan disokong oleh pengamanan sosial para pengemban kepentingan di masyarakat (stakeholder).

Stakeholder penanggulangan banjir secara umum dikelompokkan menjadi tiga bagian. Pertama, yaitu, beneficiaries, masyarakat yang mendapat manfaat/dampak secara langsung maupun tidak langsung. Kedua, intermediaries, kelompok masyarakat atau perseorangan yang dapat memberikan pertimbangan atau fasilitasi dalam penanggulangan banjir antara lain: konsultan, pakar, LSM, dan profesional di bidang SDA. Ketiga, decision/ policy makers, lembaga/institusi yang berwenang membuat keputusan dan landasan hukum seperti lembaga pemerintahan dan dewan sumberdaya air.

Partisipasi masyarakat dari ketiga bagian tersebut merupakan salah satu bentuk implementasi akuntabilitas atas program-program pemerintah, pada umumnya khususnya dalam pembangunan fisik pengendali banjir. Dengan kata lain, akuntabilitas pemerintah dapat dinilai dari sudut pandang sejauh mana partisipasi masyarakat dan pihak terkait (stakeholder) lainnya dalam program pembangunan. Partisipasi masyarakat dilakukan mulai dari tahapan kegiatan pembuatan konsep, konstruksi, operasional-pemeliharaan, serta evaluasi dan pengawasan.

Analisa dampak sosial merupakan suatu proses yang akan menjamin bahwa pelaksanaan suatu tindakan cukup terinformasikan dengan mempertimbangkan isu-isu sosial yang relevan, serta menyediakan suatu strategi partisipasi untuk melibatkan seluruh stakeholders secara luas dan aktif (Sofyan, 2016). Penentuan dan pemilahan stakeholder dilakukan dengan metode Stakeholders Analysis (Rietbergen \& Narayan, 1998).

Bertolak dari latar belakang di atas, tujuan dari asesmen di ranah sosial-ekonomi di Kota Gorontalo adalah: (1) mengetahui dan menghasilkan rekomendasi hasil penilaian masyarakat atas rencana pembangunan fisik pengendalian banjir; (2) memprediksi isu-isu kritis yang mengemuka pada tahap pra 
konstruksi, tahap konstruksi, dan paska konstruksi berikut solusi pengamanan sosialnya; dan (3) menginformasikan, mendorong hadirnya rasa memiliki, tanggung jawab stakeholders atas rencana pembangunan fisik pengendalian banjir.

\section{B. PELAKSAAAN DAN METODE}

Kegiatan FGD dilakukan di ruang serbaguna kelurahan Biawao dan Biawu Kota Gorontalo yang dilaksanakan pada tanggal 7 Maret 2017. Pendekatan yang digunakan dalam social assessment adalah kuantitatif dan kualitatif. Pemilihan wilayah kajian dan responden survey, FGD, dan wawancara menggunakan purposive sampling. Alasannya, lokasi kajian sudah diketahui secara jelas. Kegiatan social assessment dilaksanakan dengan mengumpulkan data dan informasi tentang peraturan perundangan, dokumen kebijakan lainnya, hasil kajian, dan kebijakan penanggulangan banjir yang sudah ada. Selain itu, dilakukan survey rumah tangga terhadap 50 kepala keluarga, Focus Group Disscussion (FGD) bagi kelompok masyarakat, 10 orang perempuan dan 10 orang laki-laki. Selain itu dilakukan wawancara singkat dan terarah dengan responden dari unsur-unsur: (1) pemerintah (decision/ policy makers); (2) profesional (intermediaries); (3) masyarakat umum (beneficiaries).

Analisis stakeholder dilakukan melalui 4 (empat) tahap proses yaitu: (a) identifikasi stakeholder; (b) penilaian ketertarikan stakeholder terhadap kegiatan penanggulangan banjir; (c) penilaian tingkat pengaruh dan kepentingan setiap stakeholder; dan (d) perumusan rencana strategi partisipasi stakeholder dalam penanggulangan banjir pada setiap fase kegiatan. Semua proses dilakukan dengan cara mempromosikan kegiatan pembelajaran dan meningkatkan potensi masyarakat untuk secara aktif berpartisipasi, serta menyediakan kesempatan untuk ikut bagian dan memiliki kewenangan dalam proses pengambilan keputusan dan alokasi sumber daya dalam kegiatan penanggulangan banjir. Dengan merujuk pada The World Bank and Participation: The World Bank-Operations Policy Department (1994) dan Zonneveld, Luuk, A Toolkit for Participation in Local Governance: Learning to makeparticipation work. Oxfam/Novib (Maret 2001) Tingkat partisipasi masyarakat dalam kegiatan penanggulangan banjir terdiri dari 7 (tujuh) tingkatan yang didasarkan pada mekanisme interaksinya, yaitu: (i) Penolakan (resistancelopposition); (ii) Pertukaran informasi (information-sharing); (iii) Konsultasi (consultation with no commitment); (iv) Konsensus dan Pengambilan Kesepakatan Bersama (concensus building and agreement); (v) Kolaborasi (collaboration); (vi) Pemberdayaan dengan pembagian risiko (empowerment-risk sharing); dan (vii) Pemberdayaan dan Kemitraan (empowerment and partnership).

\section{HASIL DAN PEMBAHASAN}

Stakeholder paling peduli banjir dalam pandangan masyarakat Biawao dan Biawu relatif berbeda. Dalam pandangan masyarakat Biawao hampir semua stakeholder peduli pada persoalan banjir diantaranya Dinas sosial, BNPB, warga, tokoh masyarakat, kecamatan, Badan Lingkungan Hidup, pekerjaan Umum dan RT menempati urutan pertama. Artinya mereka yang paling peduli terhadap persoalan banjir. Sementara itu, RW dan kelurahan menempati urutan nomor 2 dan Dinas kesehatan di urutan no 3. Sebagaimana diperlihatkan dalam gambar berikut ini.

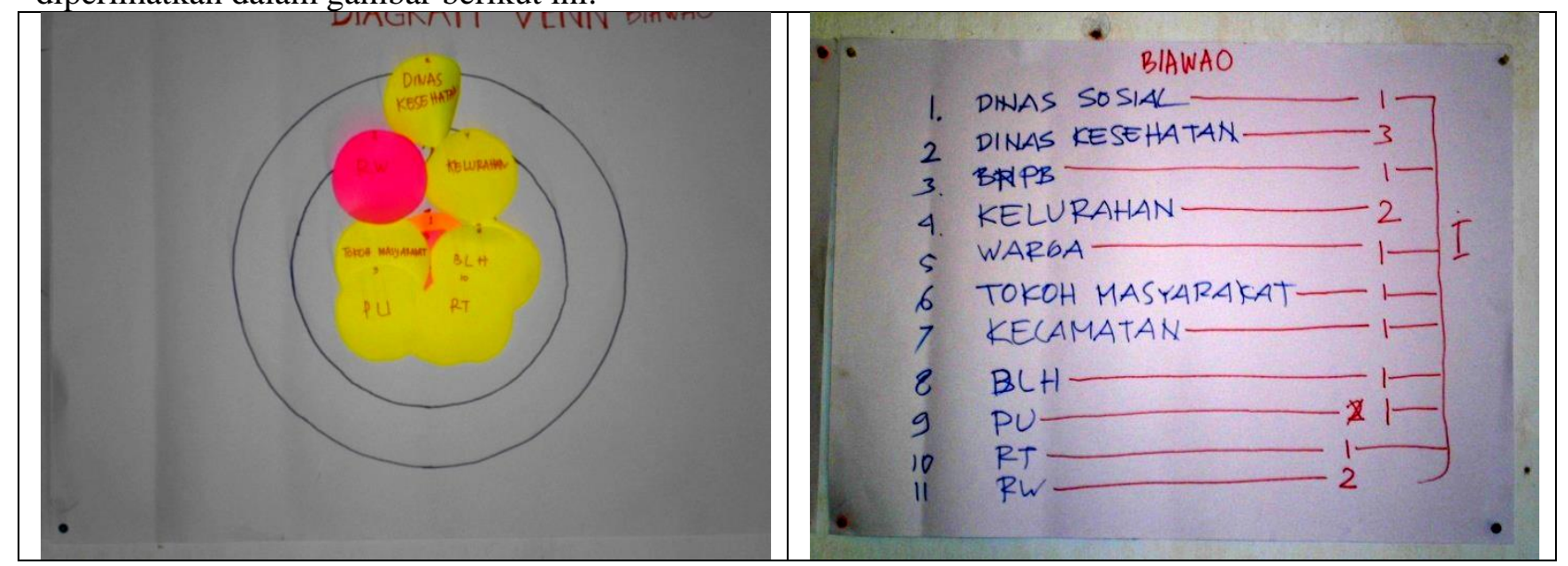

Gambar 1. Diagram Venn Kelurahan Biawao

Dalam pandangan masyarakat Biawu, Lurah, Pemkot, dan Dinas kesehatan dipandang sebagai stakehoders yang paling peduli terhadap banjir. 


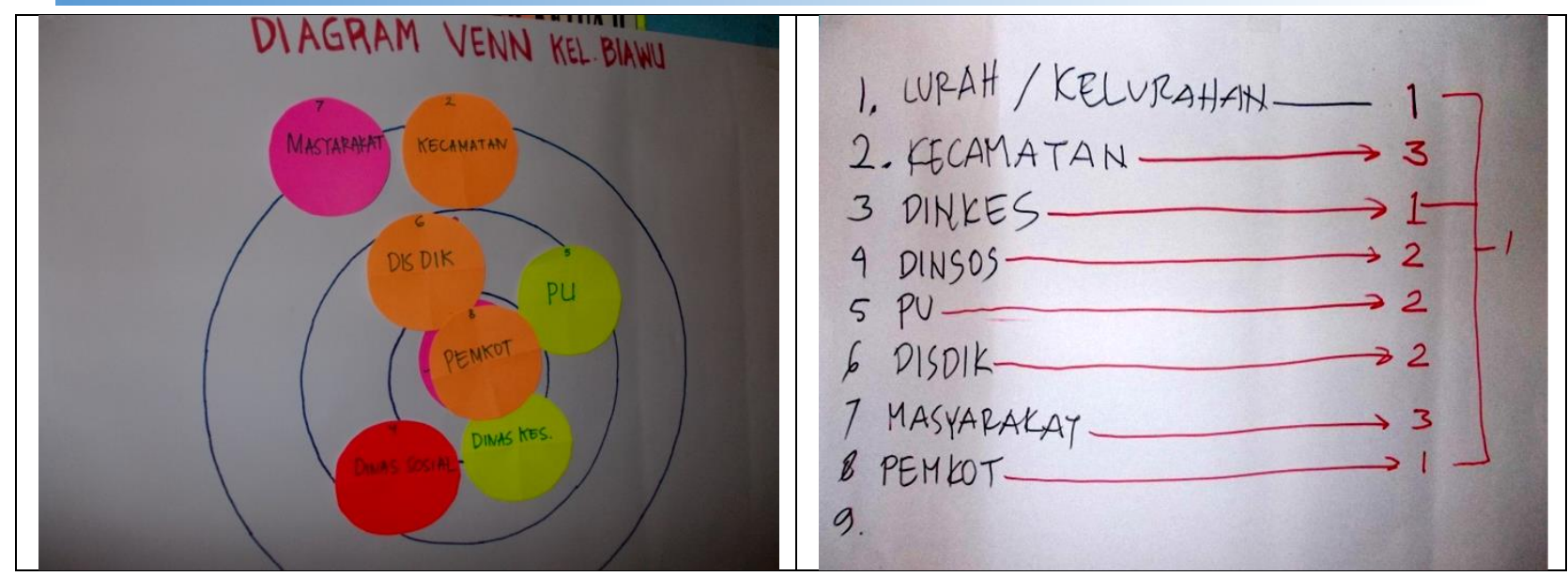

Gambar 2. Diagram Venn Kelurahan Biawu

\section{PENUTUP}

\section{Simpulan}

Keterlibatan masyarakat pada era pembangunan sekarang mutlak harus dilakukan Karena merekalah yang sesungguhnya pihak yang akan mernikmati hasil pembanguanan dan lebih jauh lagi bahwa merekalah yang sesungguhnya lebih mengetahui kondisi daerah. Keterlibatan masyarakat harus dimulai dari sejak ada timbulnya ide unuk pembangunan pengelolaan banjir dan terlibat secara langsung sampai operasi dan pemeliharaan bangunan pengendali banjir. Keterlibatan masyarakat ini mempunyai mssi disamping unuk meningkakan peran serta rasa tanggung jawab masyarakat juga dalam rangka meningkatkan kemampuan sumber daya manusia di lingkungan mereka.

\section{Saran}

Keterlibatan masyarakat pada era pembangunan sekarang mutlak harus dilakukan Karena merekalah yang sesungguhnya pihak yang akan mernikmati hasil pembangunan dan lebih jauh lagi bahewa merekalah yang sesungguhnya lebih mengetahui kondisi daerah. Agar keterlibatan masarakat dapat maksimal maka pelaksanaan proyek haraus diakukan secara tranparan, dan melibatkatkan keterwakilan masyarakat setempat dalm kegiatan mulai dari perencanaan sampai pada kegiatan operasi dan pemeliharaan. Pelibatan masyarakat ini harus tertuang dalam SOP.

\section{Ucapan Terima Kasih}

Terimakasih kepada Direktur Pengairan dan Irigasi Direktorat Sungai dan Pantai Bappenas yang telah memfasilitasi kegiatan ini, sehingga berjalan lancar dan baik.

\section{E. DAFTAR PUSTAKA}

[1]. Affeltranger, B. (2001). Public participation in the design of local strategies for flood mitigation and control. Paris: Unesco.

[2]. Bappenas. (2008). Kebijakan Penanggulangan Banjir di Indonesia. Deputi Bidang Sarana dan Prasarana, Direktorat Pengairan dan Irigasi. Jakarta: Bappenas. Retrieved from https://www.bappenas.go.id/files/5913/4986/1931/2kebijakan-penanggulangan-banjir-diindonesia_20081123002641__1.pdf

[3]. Bonacci, O. (2002). Public participation in the design of local strategies for flood mitigation and control. Hrvatske Vode , 384-386. Retrieved from http://www.vodoprivreda.net/wpcontent/uploads/2014/09/water.pdf

[4]. Instruksi Presiden. (2012). No 4 tahun 2012 tentang Penanggulangan Banjir dan Longsor.

[5]. Rietbergen, M.-J., \& Narayan, D. (1998). Participation and Social Assessment: Tools and Techniques. Washington: The World Bank.

[6]. Sofyan, M. (2016). Analisa Kepuasan Masyarakat Kota Dan Kabupaten Mojokerto Terhadap Proyek Pengendalian Banjir Perkotaan Dengan Metode Importance Performance Analysis. Eksekutif, 13(2), 320329. Retrieved from http://jurnal.ibmt.ac.id/index.php/jeksekutif/article/view/121/pdf 